\title{
The effectiveness of the leadership transformation programme among off-campus students
}

\author{
Rohana Hamzah ${ }^{1}$, Nurul Ain Fatehah Baharuddin'², Wan Jumani Fauzi ${ }^{3}$, \\ Muhamad Afzamiman Aripin ${ }^{4}$ \\ ${ }^{1,2}$ Department of Soft Skills, Centre for Human Sciences, University Malaysia Pahang, Malaysia \\ ${ }^{3}$ Centre of Modern Languages, University Malaysia Pahang, Malaysia \\ ${ }^{4}$ Faculty of Social Science and Humanities, Universiti Technology Malaysia, Malaysia
}

\begin{tabular}{l}
\hline Article Info \\
\hline Article history: \\
Received Aug 27, 2019 \\
Revised Oct 29, 2019 \\
Accepted Nov 28, 2019
\end{tabular}

\section{Keywords:}

Holistic

Leadership

Off-campus students

Social intelligence

Spiritual intelligence

\begin{abstract}
The social issues involving off-campus students are quite serious as these students are more susceptible to negative influences such as friends and the surrounding environment. Results from the preliminary study showed that there were four major problems which are relationship with the Creator, selfmanagement, social relationship with housemates, as well as housekeeping management and upkeep. Therefore, an intervention programme named Transformation Leadership Programme for Off-Campus Students was designed. The study aimed to examine the effectiveness of the leadership transformation programme among off-campus student. The effectiveness of the intervention programme reported in this study is based only on pre- and post-tests from quantitative data collected from 30 respondents. The results show that there is no significant difference for the variable, 'respondents' belief in the Creator' although the mean value increased in the post-test. Apart from that, the findings also show significant improvements in the other three variables assessed, (i.e., relationship with the Creator, self-management, social relationship with their housemates and housekeeping management and upkeep). Data also show that there was also positive impact on off-campus students' academic achievement due to the decrease in the number of respondents with CGPA below 2.5. Therefore, this means the programme is successful in helping off-campus students to understand and make a connection between the value of belief in the Creator (spiritual intelligence) with the exercise of social responsibility as a leader to oneself, others and housekeeping management and upkeep.
\end{abstract}

Copyright (C) 2019 Institute of Advanced Engineering and Science. All rights reserved.

\section{Corresponding Author:}

Rohana Hamzah,

Department of Soft Skills, Center for Human Sciences, Universiti Malaysia Pahang, 26600 Pekan, Pahang, Malaysia.

Email: rohanahamzah@ump.edu.my

\section{INTRODUCTION}

Nowadays the social problems among students in Higher Education Institutions (HEI) in Malaysia are quite serious. These social problems include students being reported to have engaged in bribery to get a pass from their lecturers [1], and to have taken drugs to stay awake so that they could study for their examinations [2]. These problems should not be ignored since university students carry the nation's hope for the country's future. If there is no intervention, it will worsen and our country will suffer, particularly in the quality of human resources. Therefore, all parties need to scrutinize this issue and focus their attention on students who live off campus as these students are usually beyond the university management's control. Therefore, the likelihood of them being affected by negative influences and engaging in risk behaviours is higher. 
In order to identify the problems among off-campus students, a preliminary study was conducted within a month among UMP off-campus students staying in the Gambang area [3]. The study used qualitative methods and non-participation observation. Seven off-campus students were chosen randomly and interviewed to find out more about their problems. Non-participation observation was done by asking the participants to take a few photos in their house such as the living room, kitchen, bedroom and bathroom to observe their housekeeping management and upkeep. Findings showed that most of the students faced problems in: (1) relationship with Creator; (2) self-management; (3) social relationship with their housemates and (4) housekeeping management and upkeep [3].

One of the self-management problems identified was related to time management. The students admitted to being late to class, submitting assignments after the due date, last minute studying for exams and many more. Problems also arose due to their weak relationship with the Creator; most of the off-campus students admitted that they often forgot to remember Allah, by missing their solat (i.e., prayers) especially their Fajr or daybreak prayer, they did not recite the Quran and more. In order to develop good personality and selfmanagement, one needs a strong connection with the Creator as the connection will develop one's internal selfcontrol [4]. A strong sense of connection with the Creator also develops the core potential of a human being which is spiritual intelligence. Spiritual intelligence is defined as "a higher dimension of intelligence that activates the qualities and capabilities of the authentic self (or the soul), in the form of wisdom, compassion, integrity, joy, love, creativity, and peace. These innate spiritual qualities are usually displayed through one's thoughts, attitudes and behaviours [5]. Being spiritual means that one's ego is dissolved, leading to one's virtue being restored to character or in other words, one's virtue becomes more positive and the connection of one's spiritual values with one's inner and outer worlds transforms positive thoughts into positive actions as a khalifah (leader) [5, 6].

The spitituality and religion may differ in form of associations, connotations and definitions, yet connected and related phenomena [7]. In a social scientific study, it is important to specify the meaning of spiritualilty so that the application, measurement and definition do not mislead to different associations, connotations and meanings [8]. From this study, spiritual intelligence is attained through faith, and worship which influences moral development [9]. This illustrates that student's need spiritual intelligence knowledge in their life to develop a good personality. Knowledge, spirituality and physical capability are among the important elements in shaping the character and personality of students holistically $[10,11]$. As such, religion is seen as the essential element that helps in addressing social problems among young people [12].

Another finding was that off-campus students also have issues with their housemates. As off-campus students spend a lot of time with their friends and housemates, they need to understand and tolerate each other in order to have a good relationship and live together harmoniously. Housemate conflict was also observed to be caused by poor upkeep and poor housekeeping management. From the observations made of off-campus students' rented houses during the preliminary study, the researcher found that in many of the houses, the condition was unpleasant, messy and disorganized. Some of the students only cleaned their own rooms rather than other places in the house for the example the living room, toilet or the kitchen. It shows that the students have individualistic behavior. This finding shows that students lack social responsibility.

Based on these problems, the researcher initiated a leadership transformation programme to help offcampus students improve their personality and to better their quality of life experience as off-campus university students. The involment of students in any extra leisure activities such as the leadership transformation programme the would also benefit them in term of the development of prosocial skills, self-efficacy, autonomy, and increased independence, personal motivation, and responsibility, as well as acting as a protective factor against risky behaviors [13]. Therefore, this programme would help them to improve their lifestyle by integrating spiritual intelligence to reinforce inner strength and create awareness on social responsibility. Hence, the objective of this research is to investigate the effectiveness of the leadership transformation programme among off-campus students which integrated spiritual intelligence to strengthen internal strength and promote awareness on the practice of social responsibility. Social responsibility is measured by the practice of justice towards the management of self, the management of others (i.e., housemates) and the management of one's environment (i.e., housekeeping management and upkeep).

\section{METHOD}

\subsection{Participants}

For the 2016/2017 academic session, the off-campus students who were registered with the Department of Student Affairs and UMP Alumni total 266 students. Since it was a challenge to get students' involvement as respondents, the researchers used non-probabilistic sampling method to select 30 students from Soft Skill II class. Soft Skills II class is a compulsory course that focuses on critical thinking and problem solving based on real problems. The students were selected based on certain characteristics. One of the 
characteristics was that they were second year students of Universiti Malaysia Pahang since findings from the preliminary study showed that students usually start living off-campus when they are in their second year. The second characteristic was that they stayed with their friends, and not their family. Of the 30 students, 14 were male students and 16 were female.

\subsection{Intervention programme}

The Leadership Transformation for Off-Campus Students Programme is an intervention programme that was specifically designed to improve the characteristics and personality of off-campus students so that their quality of life as university students is improved. This programme integrated spiritual intelligence which is belief and faith to the Creator in order to reinforce students' inner strength and to create awareness of social responsibility as a khalifah or in other words, as a leader toward oneself, others (housemates) and one's environment or physical world through housekeeping management [6]. The programme was conducted from week 4 to week 14 during the academic session. It required 10 weeks and it began with a briefing session and a pre-test. A group of students were assigned as off-campus committee members. Next is the knowledgesharing session, which took two weeks. Then, the respondents were assigned to work in groups and they had to prepare a proposal based on their housekeeping management problems. Next, they had to plan and execute a simple innovation project to solve the problem together. In week 9, a housekeeping management contest was carried out. A few lecturers were assigned as judges to visit and evaluate the participants' houses. Finally, the off-campus students' committee arranged an appreciation day and during the event, the post-test instrument was distributed. In addition, information about their CGPA was also collected after their overall results were released by their respective faculties.

\subsection{Instrument}

The method used for this study is quantitative research method [14]. Therefore, instrument used was a set of questionnaire that was developed based on the variables identified from the preliminary study and previous study $[15,16]$. It was distributed before the programme and after the programme as a pre-test (week 1) and post-test (week 10). The questionnaire was divided into 2 parts: Part A and Part B. Part A required respondent to provide personal information including their CGPA. Part B has 4 sections consisting of 40 questions and they were designed to elicit feedback from the respondents about the effectiveness of the leadership transformation programme in terms of (1) relationship with the Creator, (2) self-management (3) social leadership transformation with their housemates and (4) social transformation for housekeeping management and upkeep. Data from the questionnaire were analysed in Statistical Package for Social Science (SPSS) 23.0 using comparative analysis of the pre- and post-test mean data.

\section{RESULTS AND DISCUSSION}

This section will discuss the findings to measure the effectiveness of leadership transformation programme among off-campus students based on four variables measured which are (1) relationship with the Creator (2) self-management, (3) social leadership transformation with housemates and (4) social transformation for housekeeping management and upkeep. Further analysis was also carried out to study the impact of the programme on students' academic achievement.

Table 1 shows the findings on students' perceptions of their relationship with the Creator before and after they went through the programme.

Table 1. Relationship with the creator

\begin{tabular}{|c|c|c|c|c|}
\hline Item & $\begin{array}{l}\text { Mean Pre } \\
\text { Test }\end{array}$ & $\begin{array}{l}\text { Level } \\
\text { (Pre) }\end{array}$ & $\begin{array}{c}\text { Mean } \\
\text { Post Test }\end{array}$ & $\begin{array}{l}\text { Level } \\
\text { (Post) }\end{array}$ \\
\hline Believe in the Creator & 4.73 & High & 4.83 & High \\
\hline Believe that the Creator gives peace & 4.70 & High & 4.83 & High \\
\hline Faithful to the Creator & 4.60 & High & 4.83 & High \\
\hline Strong relationship with the Creator & 4.63 & High & 4.83 & High \\
\hline Having confidence in the Creator to feel safe & 4.56 & High & 4.83 & High \\
\hline Belief in the Creator to feel not alone & 4.56 & High & 4.90 & High \\
\hline I need to know the purpose of life because I do not feel good & 3.93 & High & 4.06 & High \\
\hline $\begin{array}{l}\text { Have confidence in the existence of the Creator so that I am capable } \\
\text { of controlling behavior }\end{array}$ & 4.40 & High & 4.63 & High \\
\hline Without religion I feel free & 4.53 & High & 4.03 & High \\
\hline Choose goodness because I realize that it is our Creator's command & 4.63 & High & 4.63 & High \\
\hline Average Mean & 4.43 & High & 4.64 & High \\
\hline Variable & $\mathrm{t}$ & \multicolumn{2}{|c|}{ df } & Sig \\
\hline Trust the Creator & -1.080 & \multicolumn{2}{|c|}{29} & 289 \\
\hline
\end{tabular}

Int. J. Eval. \& Res. Educ. Vol. 8, No. 4, December 2019: 726 - 734 
Table 1 shows that the respondents' relationship with the Creator has increased from 4.43 (pre-test) to 4.64 (post-test). Both mean values indicate that the level of respondents' relationship with Creator is high. The t-test shows that there is no significant difference as the t value (1.08) is already significant with the value already higher than 0.05. Despite that, the programme still managed to have an impact on the participants as seen in the increase in the post-test value which illustrates improved participants' relation with the Creator.

Table 2 shows the results of the second variable which reveal the effectiveness of the programme on students' self-management. Table 2 reveals that there was an increase in the average mean for transformation of self-management (leadership responsibilities toward oneself) from 3.62 (pre-test) to 4.24 (post-test). Overall, the mean score improved from moderate (pre-test) to high level in the post-test. There are several items that were at a moderate level during the pre-test but increased to a high level during the post-test. They are: time management; be able to determine a better way of life; dislike to stay up late and wake up late in the morning; I feel more responsible toward academic tasks; excited to succeed.

Table 2. Transformation in self-management

\begin{tabular}{|c|c|c|c|c|}
\hline Item & $\begin{array}{l}\text { Mean Pre } \\
\text { Test }\end{array}$ & $\begin{array}{l}\text { Level } \\
\text { (Pre) }\end{array}$ & $\begin{array}{c}\text { Mean } \\
\text { Post Test }\end{array}$ & $\begin{array}{l}\text { Level } \\
\text { (Post) }\end{array}$ \\
\hline Today is better than yesterday & 4.46 & High & 4.53 & High \\
\hline $\begin{array}{l}\text { Willing to learn and face challenge as off campus } \\
\text { students }\end{array}$ & 4.16 & High & 4.40 & High \\
\hline Time management & 3.50 & Moderate & 4.30 & High \\
\hline Be able to determine a better way of life & 3.53 & Moderate & 4.00 & High \\
\hline Dislike to stay up late and wake up late in the morning & 3.60 & Moderate & 3.70 & High \\
\hline I feel more responsible toward academic tasks & 3.40 & Moderate & 4.10 & High \\
\hline $\begin{array}{l}\text { More self-independence and responsible for self- } \\
\text { management }\end{array}$ & 4.20 & High & 4.50 & High \\
\hline Excited to succeed & 3.66 & Moderate & 4.40 & High \\
\hline $\begin{array}{l}\text { Knowledge in human sciences has helped my survival } \\
\text { as an off-campus student }\end{array}$ & 4.03 & High & 4.26 & High \\
\hline Average Mean & 3.62 & Moderate & 4.24 & High \\
\hline Variable & $\mathrm{t}$ & df & & Sig \\
\hline Transformation in Self-Management & -3.845 & 29 & & .001 \\
\hline
\end{tabular}

This finding shows that the programme has succeeded in helping off-campus students to transform their self-management to be better. The programme has also improved the determination of off-campus students to be more successful. The mean comparison derived from the $t$-test shows that there is a significant difference between pre-test and post-test $(t=-3.845, \mathrm{df}=29, \mathrm{p}<.05)$. Therefore, the programme has contributed significantly to improve self-management which is responsibility as a leader toward oneself as a basic skill to survive as off-campus students. In other words, the programme has succeeded in enabling students who participated in the programme to manage their time better and to feel more responsible toward themselves and also their academic achievement.

Table 3 shows the results of the effectiveness of the programme in transforming off-campus students' social responsibilities towards their housemates.

Table 3. Transforming social leadership with housemates

\begin{tabular}{lcccc}
\multicolumn{1}{c}{ Item } & $\begin{array}{c}\text { Mean Pre } \\
\text { Test }\end{array}$ & Phase (Pre) & $\begin{array}{c}\text { Mean } \\
\text { Post Test }\end{array}$ & $\begin{array}{c}\text { Phase } \\
\text { (Post) }\end{array}$ \\
\hline Responding to housemates positively when they make mistakes & 3.56 & Moderate & 4.13 & High \\
Accept friend's comments & 4.10 & High & 4.43 & High \\
Unaffected by the housemates doing negative activities & 2.16 & Low & 3.90 & High \\
Keep up with friends even though you've got a conflict & 4.10 & High & 4.00 & High \\
Influence housemates to do a good moral activity & 3.93 & High & 4.13 & High \\
Talk to your friends if there is any problem & 3.56 & Moderate & 3.96 & High \\
Always pray together & 2.96 & Low & 3.43 & Moderate \\
Always play/exercise together & 3.60 & Moderate & 3.90 & High \\
Off-campus life makes students closer and friendlier & 3.86 & High & 4.13 & High \\
Share personal matters with housemates & 3.50 & Moderate & 3.53 & Moderate \\
Average Mean & 3.53 & Moderate & 3.96 & High \\
\hline \multicolumn{1}{c}{ Variable } & t & & df & Sig \\
\hline Transformation Of Social Relationship With Housemates & 2.94 & & 10 & .015 \\
\hline
\end{tabular}


Table 3 shows the mean value of leadership transformation with housemates (social intelligence) has increased from 3.53 (pre-test) to 3.96 (post-test). The mean score increased from low and moderate to high levels for the following items: responding to housemates when they make mistakes; unaffected by the housemates doing negative activity; talk to your friends if you have a problem; always pray together; always play/exercise together

Findings from $t$-test show that there is a significant difference between the pre- and post-tests achievement as the $t$-value is significant at lower than $0.05(\mathrm{t}=2.94$, $\mathrm{df}=10, \mathrm{p}<.05)$. Therefore, this programme has contributed significantly to transform the social leadership skills among off-campus students. The programme has succeeded in enhancing social relationships among off-campus students and their housemates. Good social relationships among off-campus students will definitely develop a sense of love and tolerance among them and finally contribute to a better quality of life in general.

Next, Table 4 shows findings on the effectiveness of the programme on the transformation of housekeeping management and upkeep.

Table 4 Transformation of housekeeping management and upkeep

\begin{tabular}{|c|c|c|c|c|}
\hline Item & $\begin{array}{c}\text { Mean Pre } \\
\text { Test }\end{array}$ & $\begin{array}{c}\text { Phase } \\
\text { (Pre) }\end{array}$ & $\begin{array}{c}\text { Mean } \\
\text { Post Test }\end{array}$ & $\begin{array}{l}\text { Phase } \\
\text { (Post) }\end{array}$ \\
\hline Do house chores & 3.47 & Moderate & 4.33 & High \\
\hline Take an action if the house is messy & 3.16 & Moderate & 4.20 & High \\
\hline Return things to their place & 3.26 & Moderate & 3.83 & High \\
\hline Have time to arrange and clean the house & 3.33 & Moderate & 3.80 & High \\
\hline Work together to clean the house & 3.10 & Moderate & 3.63 & Moderate \\
\hline Maintain cleanliness is our responsibility & 4.43 & High & 4.23 & High \\
\hline Do not leave water tap on when brushing teeth & 3.16 & Moderate & 4.03 & High \\
\hline Housemates and I take responsibility to manage the house & 3.96 & High & 4.06 & High \\
\hline Provide a place to put some items & 3.86 & High & 4.07 & High \\
\hline Like to wash the toilet at home & 3.36 & Moderate & 3.46 & Moderate \\
\hline Feel safe and comfortable staying at home & 3.80 & High & 4.26 & High \\
\hline Average Mean & 3.53 & Moderate & 3.99 & High \\
\hline Variable & $t$ & & & Sig \\
\hline Social Transformation of House Management & 3.8 & & & .003 \\
\hline
\end{tabular}

Table 4 shows that there is an increase in the mean value for overall leadership for transformation of housekeeping management and upkeep from 3.53 (pre-test) to 3.99 (post-test). The mean score improved from moderate to high levels for the following items: do house chores; take an action if the house is messy; have time to arrange and clean the house; do not leave water tap on when brushing teeth.

The $t$-test results show that there is a significant difference between the pre- and post-tests $(t=3.98$, $\mathrm{df}=10, \mathrm{p}<.05)$. Therefore, the programme has succeeded in instilling self-awareness of housekeeping management and upkeep and it improved off-campus students' sense of responsibility towards keeping their house clean. If every off-campus student is aware of their responsibilities and is responsible toward keeping their house clean, their quality of life will be improved and this will support their academic achievement and personality development holistically. Table 5 shows the overall results for every variable measured in this study.

Table 5. Overall mean comparison

\begin{tabular}{|c|c|c|c|c|}
\hline Item & $\begin{array}{c}\text { Mean Pre } \\
\text { Test }\end{array}$ & Phase (Pre) & $\begin{array}{c}\text { Mean Post } \\
\text { Test }\end{array}$ & $\begin{array}{l}\text { Phase } \\
\text { (Post) }\end{array}$ \\
\hline Relationship with the Creator & 4.43 & High & 4.64 & High \\
\hline Transformation of Self Leadership & 3.62 & Moderate & 4.24 & High \\
\hline Social Leadership (Housemates) & 3.53 & Moderate & 3.90 & High \\
\hline $\begin{array}{l}\text { Transformation of Environment } \\
\text { (housekeeping management and upkeep) }\end{array}$ & 3.53 & Moderate & 3.99 & High \\
\hline Average Mean & 3.78 & High & 4.20 & High \\
\hline Variable & $t$ & & & Sig \\
\hline Leadership transformation & 4.84 & & & 017 \\
\hline
\end{tabular}

The overall average mean value shown in Table 5 increased from 3.78 (pre-test) to 4.20 (post-test). Findings from the $t$-test also shows that there is a significant difference between the pre- and post-tests $(t=$ $4.84, \mathrm{df}=3, \mathrm{p}<.05)$. This finding proves that after the respondents attended the Transformation Leadership Programme, there was a significant impact on self-leadership, social leadership with others (housemates) and 
social responsibility toward their environment (housekeeping management and upkeep). In other words, this programme has contributed significantly to improve the off-campus students' way of life.

Table 6 and Figure 3 both show that in terms of academic achievement, there was an increase in students' CGPA from $0 \%$ at pre-test to a CGPA of between $3.26-4.00$ at post-test $(6.7 \%)$, , as well as from $30.0 \%$ at pre-test to a CGPA of between 2.51-3.25 at post-test (60.0\%). Meanwhile, the number of students with CGPA below 2.5 decreased from 21 students to 10 students $(36.7 \%)$. This is an indirect impact of the Leadership Transformation Programme on off-campus students' academic achievement.

Table 6. Average overall grade valuation

\begin{tabular}{|c|c|c|c|c|c|}
\hline \multirow[b]{2}{*}{ CGPA } & \multicolumn{2}{|c|}{ Pre Test } & \multicolumn{2}{|c|}{ Post Test } & \multirow[b]{2}{*}{ Percent } \\
\hline & $\begin{array}{c}\text { Frequency } \\
\text { (F) }\end{array}$ & Percentage (\%) & $\begin{array}{c}\text { Frequency } \\
\text { (F) }\end{array}$ & $\begin{array}{c}\text { Percentage } \\
(\%)\end{array}$ & \\
\hline $1.00-1.75$ & 0 & 0 & 0 & 0 & \\
\hline $1.76-2.50$ & 21 & 70.0 & 10 & 33.3 & Decrease $36.7 \%$ \\
\hline $2.51-3.25$ & 9 & 30.0 & 18 & 60.0 & Increased $30 \%$ \\
\hline $3.26-4.00$ & 0 & 0 & 2 & 6.7 & Increase $6.7 \%$ \\
\hline Total & 30 & 100.0 & 30 & 100.0 & \\
\hline
\end{tabular}

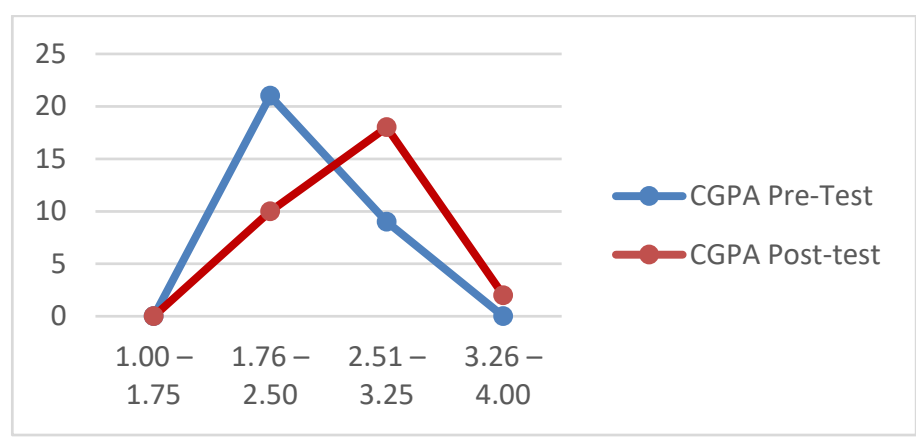

Figure 3. Number of students and CGPA before and after programme

The findings show that this programme has proven that while developing social intelligence is possible, it is incomplete without the integration of spiritual intelligence, which develops in students a strong sense of responsibility as a leader in managing oneself as well as developing good social connection or relationship with others including one's environment. The development of social intelligence without spiritual intelligence as its foundation will cause the education process to be void of guidance and subsequently, lead to the failure of developing a strong sense of responsibility among human beings $[17,18]$.

It has been proofed by many researches that the sense of being monitored by a trustworthy and supportive entity will help people to cope with their risk behavior [19]. The findings of this study indicate that the off-campus students who were selected for this study fortunately already had a strong belief in God AlMighty, the One they believed that always monitoring their life. Nevertheless, after following the programme, there was still a slight increase in this variable. This finding proves that a good training can further improve and increase spiritual intelligence [20]. Due to the existing strong connection with the Creator that they already have, the difference shown between pre- and post-tests does not seem that significant. However, this finding was consistent with a study conducted by a researcher who integrated the value believing in God in teaching and learning activities for Malaysian prison instructors. The research revealed that Malaysian people do not isolate themselves from the sense of having a connection with God in their life [21, 22].

However, there were significant improvements and changes in the other three variables assessed namely the transformation of self-leadership, the transformation of social leadership (housemates) and the transformation of environment leadership (housekeeping management and upkeep). Therefore, the implementation of the Leadership Transformation Programme among off-campus students has helped them to make a stronger connection between the values of belief in God (spiritual intelligence) and to demonstrate that value better by being a more responsible leader to oneself, to others and to their environment [6]. This result proved that spiritual intelligence has a positive effect on ethical attitude [23]. Furthermore, this finding also shows that spiritual intelligence allows its association with rational thinking or intellectual intelligence and helps individuals to move in the direction to play their role as a leader more effectively [20, 23]. Moreover, spiritual intelligence also will enhance the living conditions as the individual can now place their actions and 
their lives in a wider perspective and meaning [24] as their actions no longer go through their 'ego' filter, making them naturally virtuous [25].

Therefore, a holistic self-transformation process requires the awareness of the purpose of life as a slave to Creator by strengthening their faith using integrated knowledge development approaches and then exercising this responsibility as a caliph or a leader that develops positive change continuously to oneself, others and in the environment where they live [26, 27]. In other words, it is our responsibility to rearrange our life according to Allah's command by understanding what does God want me to do [28]. Self-awareness about God's command will develop positive emotional and rational thinking ability in facing any problem and finally improve our action to be more positive as a proof of our faith and gratitude to the Creator [29, 30]. Hence, developing leadership skills by integrating spiritual awareness will foster a high sense of responsibility $[28,31]$.

\section{CONCLUSION}

All in all, the findings show that all the variables are interrelated. Although the first variable, relationship with the Creator, may not have shown a significant increase, it is however the foundation for all the other variables (i.e., self-management, social relationship with housemates and, housekeeping management and upkeep) which are actually the practical aspects of one having a strong bond with the Creator. Therefore, although the finding for the first variable showed that the bond was already strong, it was not really translated in the actions of the off-campus students. This means that in terms of knowledge, the respondents had strong awareness, but in terms of practice, how the students managed themselves, managed their social relationships with their housemates and managed and maintained the upkeep of their rented houses were still lacking. After the intervention programme, the results of the post-test showed that the off-campus students improved in all the variables. This shows that the respondents' knowledge and practice are now balanced. Their strong bond with their Creator is now demonstrated in their actions.

This study aligned with many other findings as discussed previously. The involment of students in a leadership transformation programme have benefited them in term of the development of a holistic being. In addition, the sense of being monitored by God as a trustworthy and supportive entity has helped the students to improve their self, their social skills and their environmental awareness.

Therefore, the researcher recommends that this programme to be continually implemented in future in Universiti Malaysia Pahang to develop better individuals, regardless if they are on or off-campus students. This will create future engineers and technologists who not only have a strong bond with the Creator as stated in UMP core values but who will also have a stronger sense of responsibility as a leader to lead themselves, and their society toward goodness as well as a leader who cares for the environment. Moreover, the implementation of the Leadership Transformation Programme for off-campus students will also make their life experiences as university students more meaningful. They will feel that even as off-campus students, they are not neglected or left behind by the management of the university. Therefore, this programme will also contribute in developing a more holistic and comprehensive university student management system.

\section{ACKNOWLEDGEMENTS}

The authors would like to express their gratitude to Universiti Malaysia Pahang for providing financial assistance under project no. RDU1603145. The authors would also like to thank all the students who participated in this research.

\section{REFERENCES}

[1] Berita Harian Online, "Students of HEI meritorious lecturers for pass grade," [Onilne] Available https://www.bharian.com.my/node/205166, 2016.

[2] The Star Online, "University students are playing as low as RM5 for drugs," [Online] Available https://www.thestar.com.my/news/nation, 2017.

[3] Rohana Hamzah and Nurul Ain Fatehah, "A pilot study of the development of an out-of-school student selftransformation module (in Malay)," International Journal of Humanities Technology and Civilization (IJHTC), vol. 1(4), pp. 36-57, 2018.

[4] Tajulashikin Jumahat \& Nor Faizah Abdullah, "Comparison of spiritual intelligence concepts from islamic and western perspectives: a review (in Malay),"in Proceeding of the International Conference on Arabic Studies and Islamic Civilization. iCasic 2014, pp. 4-5, Mar 2014.

[5] Johnson Mathew, "Factor of spiritual intelligence," International Research Journal of Management Sociology \& Humanity, vol 3(3), pp 705-708, 2012. 
[6] Muhamad Al-Mahdi, "Understanding the concept of khalifah; khalifah series no.1," The Kalifah Institute: Selangor, 2014.

[7] Yusuf Kurt, Noemi Sinkovics, Rudolf R. Sinkovics and Mo Yamin, "The role of spirituality in Islamic business networks: The case of internationalizing Turkish SMEs," Journal of World Business, pp 1-14, 2020.

[8] Philip Clayton and Zachar Simpson (eds.), "The Oxford Handbook of Religion and Science," Oxford Unversity Press, 2006.

[9] Oki Dermawan, "Build students' character through fasting at Muslim school," Quality, vol. 5(1), pp. 40-56, 2018.

[10] Nurul Haerani \& Ahmad, "Holistic human capital development through polytechnic curriculum activities (in Malay)," Published by University Tun Hussien Onn Malaysia, 2013

[11] Syed Muhammad Naquib al-Attas, "Prolegomena to the metaphysics of islam: an exposition of the fundamental elements of the wordview of islam," Kuala Lumpur: ISTAC, 2001.

[12] Fauziah Ibrahim, et al., "Empowering religious knowledge among adolescents with behavioral disorders: towards the formation of moral adolescents (in Malay)," Published by University Kebangsaan Malaysia, 2012.

[13] Clarke S, Allerhand LA and Berk MS. "Recent advances in understanding and managing self-harm in adolescents [version 1; peer review: 2 approved]," F1000Research, pp 1-12, 2019.

[14] Creswell John W., "Research Design: Qualitative, Quantitative, and Mixed Methods Approaches (Third Edition)," SAGE Publications : United State of America, 2009.

[15] Rabia Dasti, Aisha Sitwat, "Development of a multidimensional measure of Islamic spirituality (MMS)," Journal of Muslim Mental Health, vol. 8(2), pp 47-67, 2014.

[16] Steven Eric Krauss, Azimi Hamzah and Fazila Idris, "Adaptation of a Muslim religiousity scale for use with four different faith communities in Malaysia," Review of Religious Research, vol. 49(2), pp 147-164, 2007.

[17] Mohd. Janib Johari, "Morals, application theory \& issues (in Malay)," Pubished by Perpustakaan Negara Malaysa, 2001.

[18] Hamdan Muhammad \& Muhammad Najumuddin 'Ulwan, "Curriculum from heaven (in Malay)," Kemilau Publika Sdn Bhd. Selangor, 2013.

[19] Alonso Ruiz, R. A., Valdemoros San Emeterio, M. Á., Sáenz de Jubera Ocón, M., \& Sanz Arazuri, E., "Family leisure, self-management, and satisfaction in spanish youth," Frontiers in Psychology, pp 1-8, 2019

[20] Maryam Hosseini, et al., "A review study on spiritual intelligence, adolescence and spiritual intelligence, factors that may contribute to individual differences in spiritual intelligence and the related theories, "Journal of Social Sciences, vol. 6 (3), pp. 429-438, 2010.

[21] M. A. Aripin, et al., "Content reliability measurement of holistic approach training module," International Journal of Pure and Applied Mathematics, vol. 118(24), pp 1-13, 2018.

[22] M. A. Aripin, "Holistic approach training module for prison training skills department of prison Malaysia," UTM: Thesis Phd, 2017.

[23] Putu Indra Wiguna and Ketut Yadnyana, "The role of working experience moderating the effect of emotional intelligence, intellectual intelligence and spiritual intelligence on the ethical decision of tax consultants in Bali area," International Research Journal of Management, IT \& Social Sciences, vol. 6 (3), pp. 18-28, 2019.

[24] Sheetal Deolalkar, "Spiritual intelligence develops innovators," Scholarly Research Journal For Humanity Science and English Language, vol. 1, pp. 572-578, 2014.

[25] Mohd. Suhardi Mat Jusoh et.al., "The development of student's spiritual intelligence based on Tazkiyah al-Nafs alGhazali Model at Universiti Malaysia Pahang (UMP)," International Journal of Humanities Technology and Civilization (IJHTC), vol. 1(4), pp. 74-91, 2018.

[26] Rohana Hamzah, et al., "Development of educated souls in the future of educators (in Malay)," Jurnal Teknologi, vol. 61(1), pp. 27-31, 2013.

[27] Creswell John W., "Research Design: Qualitative, Quantitative, and Mixed Methods Approaches (Third Edition)," SAGE Publications : United State of America, 2009.

[28] Jacobus Kok and Steven C. van den Heuvel, "Leading in a VUCA world: integrating leadership, discernment and spirituality," Springer: Switcerland, 2019

[29] Wan Mohd. Nor Wan Daud, "Philosophy and practice of islamic education; Syed M. Naquib Al-Attas: A description of the original concept of islamization (in Malay)," Kuala Lumpur: Universiti Malaya, 2005.

[30] Rohana Hamzat et al., "Integration of spiritual intelligence in modern tools for creativity and innovative thinking using theory of inventive problem solving (TRIZ)," International Journal of Humanities Technology and Civilization (IJHTC), vol. 1(5), pp. 1-9, 2019.

[31] Putu Harry Krisnanda and Ida Bagus Ketut Surya, "Impact of emotional and spiritual intelligence on transformational leadership and employee performance," International Research Journal of Management, IT \& Social Sciences, vol. 6(3), pp. 70-82, 2019. 


\section{BIOGRAPHIES OF AUTHORS}
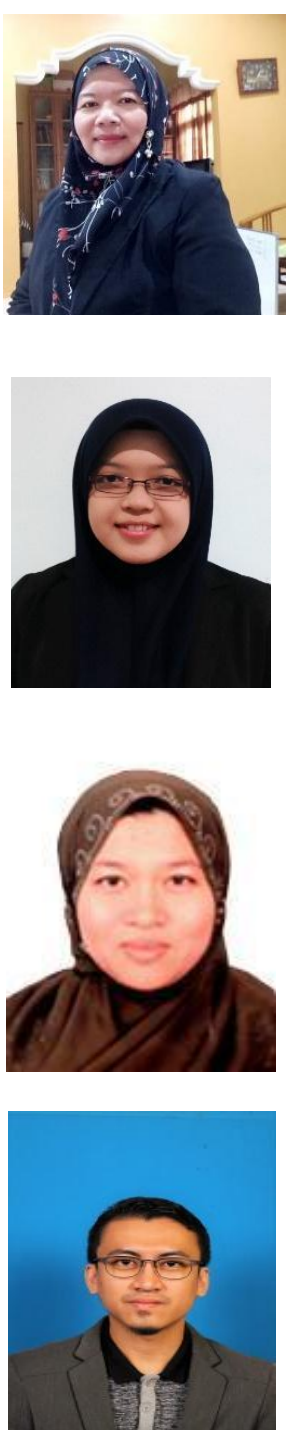

Rohana Binti Hamzah, is currently a Head of Soft Skills Department and senior lecturer at the Centre for Human Sciences, Universiti Malaysia Pahang, Malaysia. She obtained him PhD in Art and Design from Unversiti Teknologi Mara (UiTM). With more than 19 years of experience as academician, she has supervised more than 15 students at Master and $\mathrm{PhD}$ level and led more than 5 research grants at internal and national level. She has published more than 20 articles, 5 books and a few articles in newpaper. She also involved in training with government and private sectors for parenting, soft skills and human development issues. Her research interest is holistic and integrated education, TVET education, spiritual and emotiona intelligence, soft skills and instructional design.

Nurul Ain Fatehah binti Baharuddin obtained her Master in the field of Human Performance System from University Malaysia Pahang (UMP). Her research interest in holistic and integrated education, spiritual intelligence, soft skills and instructional design. She has published a few articles related with her research interest area.

Wan Jumani Fauzi, $\mathrm{PhD}$, is currently a senior lecturer at the Centre for Modern Languages, Universiti Malaysia Pahang, Malaysia. With more than 18 years of experience in teaching, she is also involved in trainings with government and private sectors teaching English communication skills. Her research addresses issues in applied linguistics, sociopragmatics such as (im) politeness. Heremail is jumani@ump.edu.my.

Muhamad Afzamiman bin Aripin obtained his $\mathrm{PhD}$ in the field of Technical and Vocational Education from Universiti Teknologi Malaysia (UTM). His research and focus of interest is TVET education, correctional education, module development and holistic and values education. He has authored more than 20 article papers in his research interest area, published a book and wrote a few articles in newspapers. He had work in several education institutions as administration and academic staff and currently work as Senior Lecturer in UTM 